\title{
A North American ammonite fauna from the late Middle Turonian of Vaucluse and Gard, southern France: the Romaniceras mexicanum, Prionocyclus hyatti and Coilopoceras cf. springeri association
}

\author{
FRANCIS AMÉDRO ${ }^{1}$, FRANCIS ROBASZYNSKI $^{2}$, BERTRAND MATRION $^{3}$ \\ and CHRISTIAN DEVALQUE ${ }^{4}$ \\ 126 rue de Nottingham, 62100 Calais, France and Université de Bourgogne, UMR 6282, CNRS \\ Biogéosciences, 6 boulevard Gabriel, 21000 Dijon, France. E-mail : francis.amedro@free.fr \\ ${ }^{2}$ Université de Mons, Faculté Polytechnique, Département Mines-Géologie, 9 rue de Houdain, 7000 Mons, \\ Belgique and 57,rue Desmortiers, 17100 Saintes, France. E-mail: francis.robaszynski@umons.ac.be \\ ${ }^{3} 1$ ter rue du Pont, 10450 Bréviandes, France and Université de Bourgogne, UMR 6282, CNRS Biogéos- \\ ciences, 6 boulevard Gabriel, 21000 Dijon, France.E-mail: bertrand.matrion@sfr.fr \\ ${ }^{4} 30 b i s$ avenue Charles de Gaulle, 84420 Piolenc, France.
}

\begin{abstract}
:
Amédro, F., Robaszynski, F., Matrion, B. and Devalque, C. 2016. A North American ammonite fauna from the late Middle Turonian of Vaucluse and Gard, southern France: the Romaniceras mexicanum, Prionocyclus hyatti and Coilopoceras cf. springeri association. Acta Geologica Polonica, 66 (4), 729-736. Warszawa.

An unusual, exotic, ammonite fauna including Romaniceras mexicanum Jones, 1938, Prionocyclus hyatti (Stanton, 1894) and Coilopoceras cf. springeri Hyatt, 1903 is recorded from the late Middle Turonian of Vaucluse and Gard, southern France. It is the first record of this ammonite association outside the Gulf Coast region and the Western Interior of the United States of North America. Up to present, these species were considered as endemic to the Western Interior sea-way. The migration of numerous ammonites from North America to western Europe during the late Middle Turonian suggests it is linked to a transgressive event or to a short sea-level high.
\end{abstract}

Key words: Cretaceous; Turonian; Ammonites; Transgressive event; Migration; North America; Southern France.

\section{PREFACE}

This paper renders a tribute to Bill Cobban (19162015) who devoted his life to the study of Cretaceous ammonite faunas of North America and especially those of the Western Interior of the United States. His works and his scientific contributions are considerable. To take just two examples, he was one of the first to show the intraspecific morphological variability of Cretaceous ammonites through the remarkable study of the Upper Albian Neogastroplites of the Western Interior of the United States and of Canada (Reeside and Cobban 1960). More recently, his studies carried out with Jim Kennedy near Pueblo, in Colorado, allowed the fixing of the GSSP - Global boundary Stratotype Section and Point - of the base 
of the Turonian stage (Kennedy, Walaszczyk and Cobban 2000). For this goal they used the rich assemblages of fossils collected by Bill over many decades in the Western Interior. We refer to these works when, on several occasions, in northern Africa as in western Europe, one of us (F.A.) found unusual and exotic ammonites known until then only in the Western Interior: Prionocyclus novimexicanus (Marcou, 1858) in the Upper Turonian of Central Tunisia (Amédro in Robaszynski et al. 1990), Acanthoceras amphibolum Morrow, 1935 and Paraconlinoceras aff. barcusi (Jones, 1938) in the Middle Cenomanian of Central Tunisia (Amédro in Robaszynski et al. 1994), Metengonoceras teigenense Cobban and Kennedy, 1989 in the Lower Cenomanian of Normandy, France (Amédro et al. 2002) and, lastly, the association being the subject of the present paper, with Romaniceras mexicanum Jones, 1938, Prionocyclus hyatti (Stanton, 1894) and Coilopoceras cf. springeri Hyatt, 1903, in the late Middle Turonian of south-east France (Amédro and Devalque in Robaszynski et al. 2014). On each of these occasions Bill Cobban in Denver and Jim Kennedy in Oxford welcomed them and agreed to examine representative specimens of these ammonites, and discuss their determinations, even sending casts of the types of North American species for comparison with our material. Thank you Bill, thank you Jim!

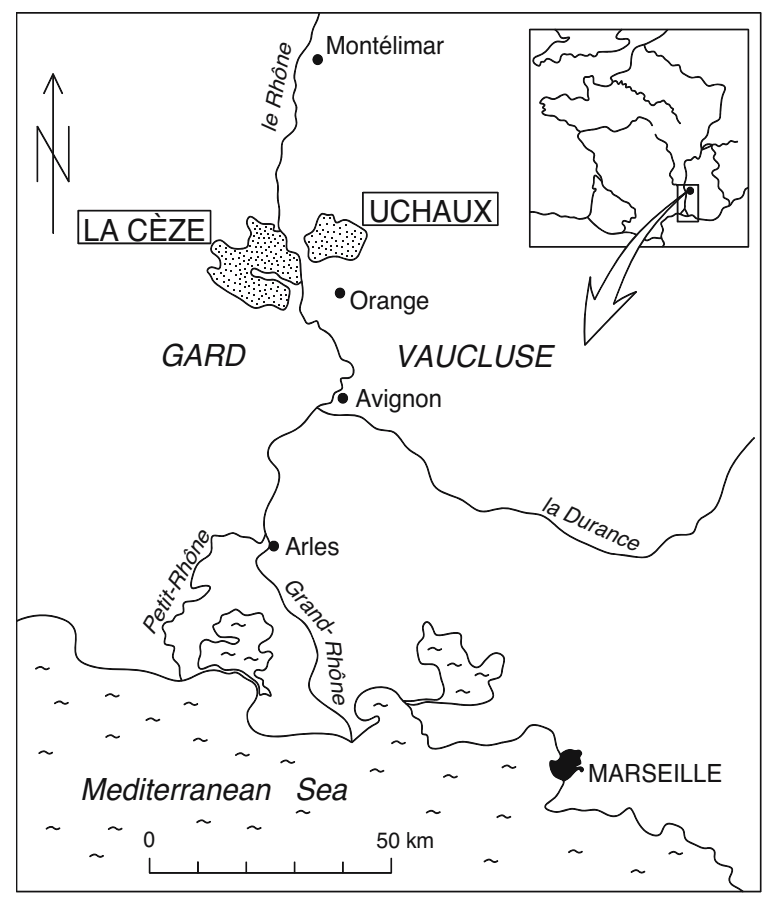

Text-fig. 1. Geographical map of southern France, including the location of the Uchaux massif on the left bank of the Rhône (Vaucluse) and the la Cèze massif on the right bank (Gard)

\section{INTRODUCTION}

Situated in the south-east of France, the Uchaux and la Cèze massifs (Text-fig. 1) have been known all over the world since the $19^{\text {th }}$ century through the works of Alcide d'Orbigny (1840-1842, 1852). This fame is due to the presence in the Uchaux red sandstones of an exceptionally rich and diversified Upper Turonian ammonite fauna, described firstly by d'Orbigny, then by Roman and Mazeran (1913) and recently revised by Wright (1979), Kennedy et al. (1980), Kennedy (1984), Kennedy and Wright (1984) and finally by Amédro and Devalque (in Robaszynski et al. 2014). The types of six ammonite species come from these Uchaux sandstones: Scalarites gracilis (d'Orbigny, 1841), Baculites undulatus (d'Orbigny, 1850), Worthoceras rochatianum (d'Orbigny, 1850), Coilopoceras requienianum (d'Orbigny, 1841), especially Romaniceras deverianum (d'Orbigny, 1841) and Subprionocyclus bravaisianus (d'Orbigny, 1841) [= S. neptuni (Geinitz, 1850)] which are the index species of the current two first ammonite zones of the Upper Turonian, following the recommendations expressed during the Colloquium on the Turonian held in Paris in 1981 (Robaszynski 1983).

The interest of the Uchaux and la Cèze massifs is not limited to the Upper Turonian as it concerns also the Middle Turonian. The methodical collecting of ammonites in the two massifs by one of us (C.D.) during four decades led the amassing of about 2000 specimens, of which 200 came from the Middle Turonian and were sufficiently diverse to allow us to distinguish four successive zones in that substage (Text-fig. 2), of Kamerunoceras turoniense (Tm1), Romaniceras kallesi (Tm2), Romaniceras ornatissimum (Tm3) and Romaniceras mexicanum (Tm4). The last of these zones is new, previously unknown in western Europe, and marked by the presence of species considered endemic and restricted to the Gulf Coast region and the Western Interior.

Below is a short account of the main litho-and palaeontological aspects of the Uchaux and la Cèze massifs. Details of the successions measured and described during the field work progressively and intermittently carried out from 1980 to 2010 are recorded in the memoir of 197 pages, 46 figures and 48 plates, recently published by the Belgian Academy of Sciences (Robaszynski et al. 2014). This gives all particularities and characteristics relative to the sections, their correlation, their palaeontological content, the systematic position of the ammonites species collected etc. Some of the illustrations of the present paper are taken from the memoir, with permission, and adapted to a new text. 


\section{THE TURONIAN OF THE UCHAUX MASSIF}

The geographical location of the Uchaux and la Cèze massifs, north of the city of Orange, on both sides of the river Rhône is given on Text-fig. 1. The succession of strata exposed in the Uchaux massif, in the Department of Vaucluse, was studied repeatedly, particularly by Hébert and Toucas (1875), Mennessier (1950), Devalque et al. (1983), and more recently by Robaszynski et al. (2014), where Amédro and Devalque proposed a revision of ammonite and rudist faunas with all specimens placed on measured lithological logs. The main results of this last work are summarised on Textfig. 2. Three formations can be recognized in the Uchaux massif, from base to top:

1. The Roustan Formation (Lower Turonian to Middle Turonian pro parte), units 1 to 3, composed of white sandstones resting on a conglomeratic level and overlain by an alternation of sandstone tempestites and silty sandstones, $250-300 \mathrm{~m}$ thick, they contain very few fossils;

2. The Massillan Formation (Middle Turonian p.p. to Upper Turonian p.p.), units 4 to 9 , succession of sandstones and sandy limestones, 150 to $180 \mathrm{~m}$ thick, with fossiliferous layers;

3. The Montmout Formation (late Upper Turonian), units 10 and 11 , about $300 \mathrm{~m}$ thick, mainly composed of sands with sandstone layers showing cross-stratification; fossils are very rare.

Each of these formations is divided into members subdivided further into several lithologic units numbered from 1 to 11 . The typical "Uchaux red sandstones" containing silicified fossils correspond to units 7 and 8 . The Uchaux sandstones sensu lato correspond to units 6 to 9 .

The distribution chart (Text-fig. 2) shows well Upper Turonian succession of two zones corresponding to two associations: the Romaniceras deverianum Zone (units 6 and 7) followed by the Subprionocyclus bravaisianus Zone (units 8 to 10). In the lower half of the Middle Turonian, the Kamerunoceras turoniense and the Romaniceras kallesi Zones are not clearly identified when it is the contrary into the sequence in the la Cèze massif where the two zones are well represented. Higher in the sequence, the Romaniceras ornatissimum Zone is characterized by the presence of the index species, but one of the major interests of the chart is to reveal the existence, between the $R$. ornatissimum and the $R$. deverianum Zones, of a new zone, not previously recognised in Europe : the Romaniceras mexicanum Zone (from the top of unit 3 to units 4 and 5). In total, 205 ammonites were collected in the R. mexicanum interval: Puzosia cf. mayoriana (d'Orbigny, 1841) (four specimens), Lewesiceras peramplum (Mantell, 1822) (18 speci- mens), Romaniceras (Romaniceras) mexicanum Jones, 1938 (69 specimens), Masiaposites kennedyi Amédro and Devalque, 2014 (14 specimens), Prionocyclus hyatti (Stanton, 1894) (eight specimens), Collignoniceras woollgari regulare (Haas, 1946) (49 specimens), Collignoniceras uchauxiense Amédro and Devalque, 2014 (33 specimens) and Coilopoceras cf. springeri Hyatt, 1903 (10 specimens).

\section{THE TURONIAN OF THE LA CÈZE MASSIF}

The la Cèze massif is situated in the Department of Gard, about $15 \mathrm{~km}$ south-east of the Uchaux Massif, on the right bank of the Rhône. During Turonian times, the la Cèze area was in a very marginal environment where the deposits were principally sandy. The stratigraphical succession was studied in the past especially by Hébert and Toucas (1875), Sornay (1950) and more recently by Robaszynski et al. (2014). As sedimentation was affected by rapid lateral facies variations, it is very difficult in the field to define and to follow lithological units as was possible on the other side of the Rhône. So, it seemed not pertinent to draw a synthetic lithological log nor a distribution chart for the area. Nevertheless, the Lower Turonian and the lower half of the Middle Turonian are very well exposed, and yielded rich ammonite faunas (more than 1000 specimens) from the Fagesia catinus Zone to the Romaniceras kallesi Zone. Above, the outcrops are generally covered with vegetation. Only one area, localized near the Signal de Pignet, on the northern side of the la Cèze Massif, yielded three species of the Romaniceras mexicanum Zone: $R$. mexicanum, C. woollgari regulare and P. hyatti.

\section{THE ROMANICERAS MEXICANUM, PRIONOCY- CLUS HYATTI AND COILOPOCERAS CF.} SPRINGERI FAUNA: A MIGRANT ASSOCIATION ORIGINATED FROM NORTH-AMERICA

The collecting of 89 specimens of Romaniceras mexicanum, Prionocyclus hyatti and Coilopoceras cf. springeri (see Plates 1-3) at the top of the Middle Turonian in the Uchaux and la Cèze massifs in south-east France is especially interesting in so far as this association was until now known only in northern America. The palaeogeographic reconstructions of North America during Turonian times given by William and Stelck (1975), Smith et alii (1994) and Roberts and Kirschbaum (1995) shows a wide interior sea in the Western Interior of the United States linked to the south with the Gulf of Mexico. During the Middle and Upper Turonian, the am- 
monites living in the Western Interior were essentially endemic and show the presence of five successive associations with Prionocyclus and Coilopoceras (Cobban and Hook 1979; Cobban 1984; Kennedy et al. 2001). The first association is characterized by the species Prionocyclus hyatti linked to Coilopoceras springeri and to Romaniceras (Romaniceras) mexicanum.

Text-fig. 3 illustrates the geographic range of the three species on the Turonian palaeogeographical map. The spreading of $P$. hyatti covers all the Western Interior sea and extends to the south to the Gulf of Mexico but that of $R$. mexicanum and $C$. springeri seem restricted to the south part of the Western Interior and to the Gulf Coast region (Cobban and Hook 1980; Kennedy and Cobban 1988 a, b; Kennedy et al. 1989). Outside the Western Interior, the only occurrences of the species concerned are these described in southern France, at first in the Uchaux and la Cèze massifs (Amédro and Devalque in Robaszynski et al. 2014) and then in the Corbières (Kennedy et al. 2015), excepted for Prionocyclus hyatti for which only one quotation was given in Kazakhstan (Marcinowski et al. 1996).

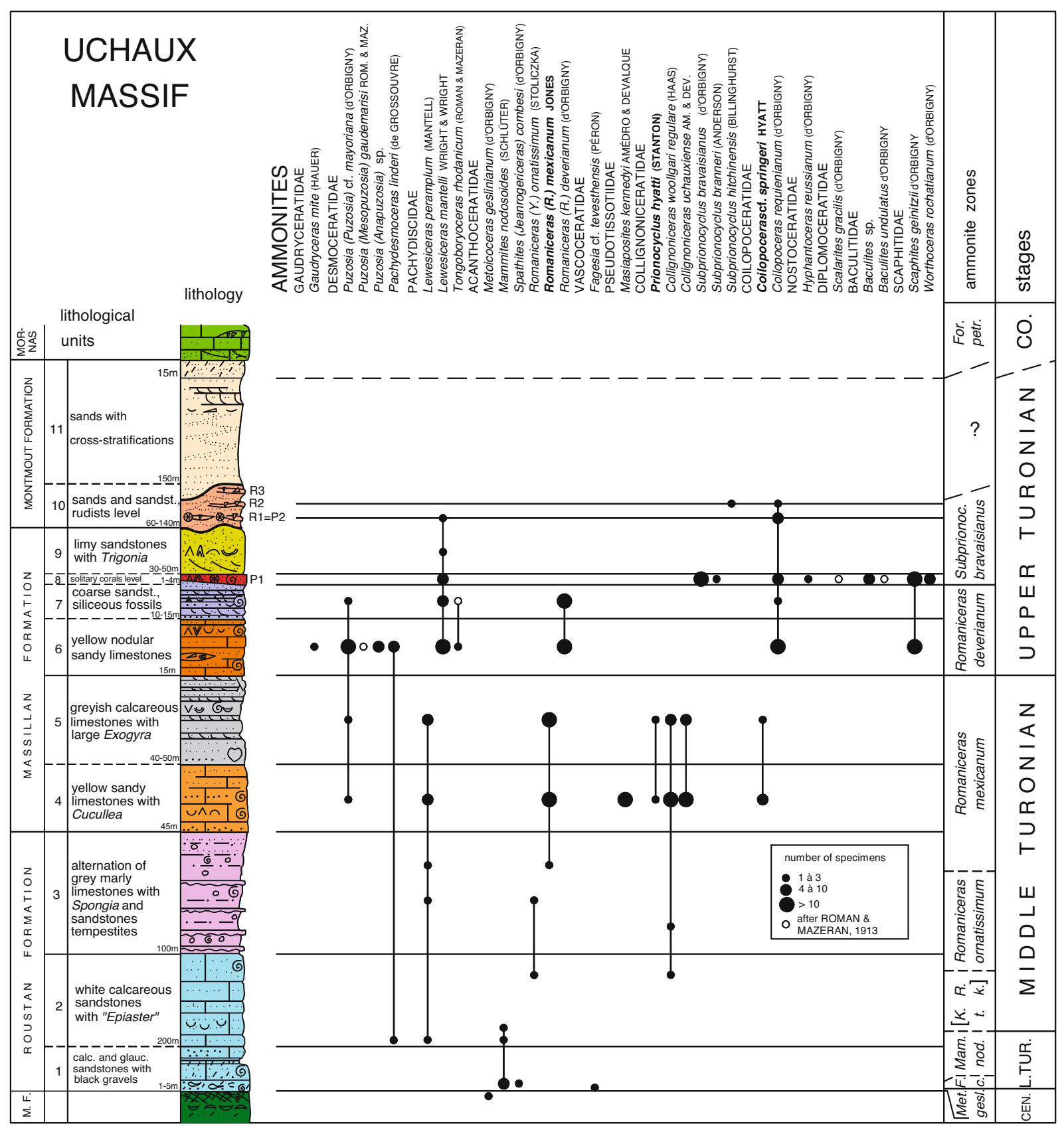

Text-fig. 2. Generalized succession of the Turonian formations in the Uchaux massif (Vaucluse, southern France) and ammonite ranges and zonation 


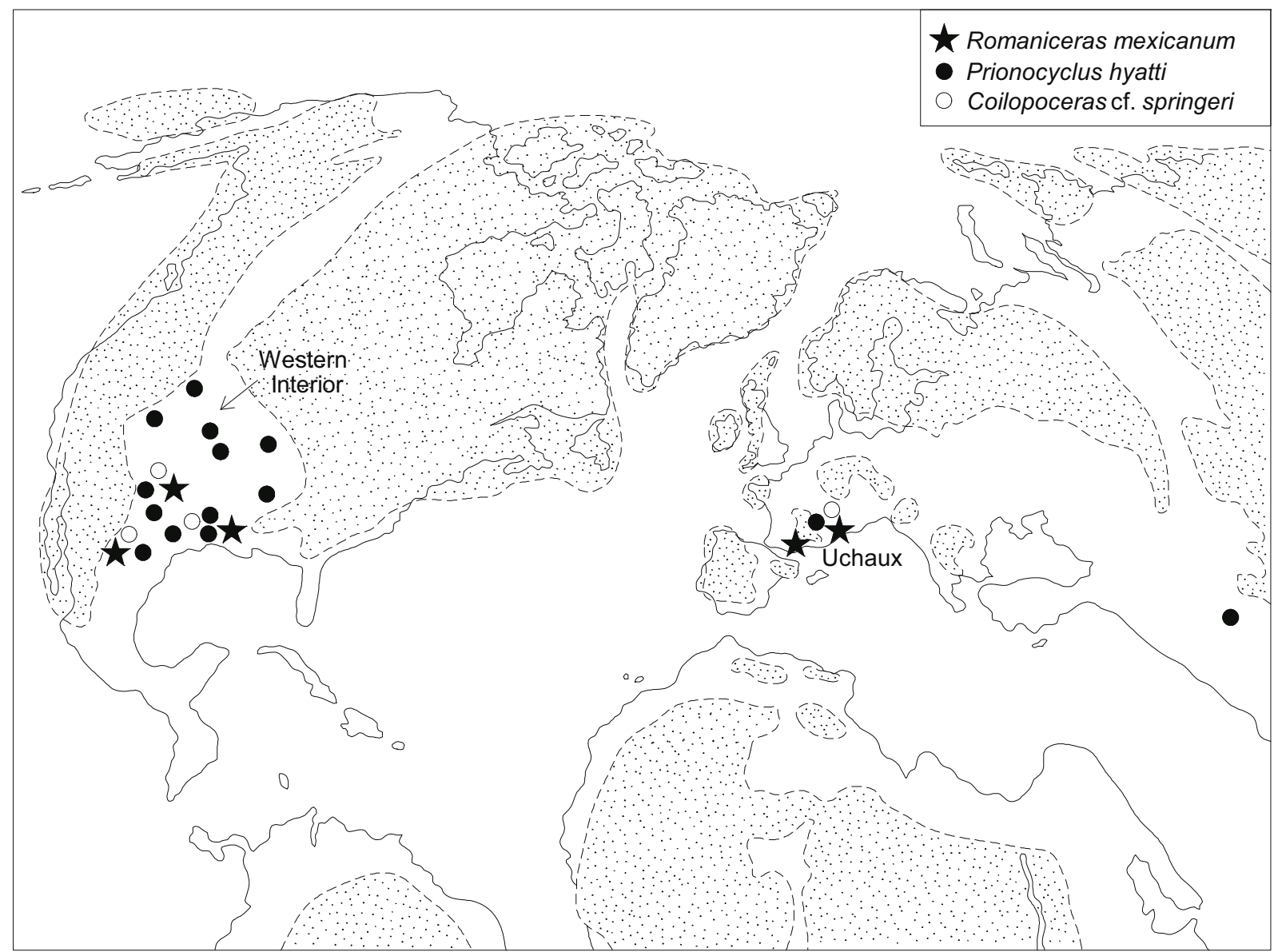

Text-fig. 3. Turonian sketch of North America and western Europe with the palaeogeographical extension of Romaniceras mexicanum, Prionocyclus hyatti and Coilopoceras springeri. During the late Middle Turonian, the ammonite faunas of the Western Interior were endemic. The discovery of numerous $R$. mexicanum,

$P$. hyatti and $C$. cf. springeri in southern France suggest a transgressive event and a migration between the two areas

The finding of numerous specimens of $P$. hyatti, $R$. mexicanum and $C$. cf. springeri in association in the high Middle Turonian of the Uchaux and la Cèze massifs allows for the first time the establishment of a direct correlation line between North America and Europe, and more particularly between the $P$. hyatti Zone of the Western Interior and the $R$. mexicanum Zone of south-eastern France (Text-fig. 4). On the one hand, if the base of the Upper Turonian is defined by the first appearance of the ammonite Romaniceras (R.) deverianum (d'Orbigny, 1841) as recommended during the Colloquium on the Turonian stage held in Paris in 1981 (Robaszynski 1983), the boundary between Middle and Upper Turonian has to be placed at the top of the Prionocyclus hyatti Zone in North America, in agreement with the proposal by Hancock et al. (1993). On the other hand, if we follow our British colleagues and the appearance of the ammonite species Subprionocyclus bravaisianus (d'Orbigny, 1841) [of which S. neptuni (Geinitz, 1850) is a junior synonym, see discussion in Robaszynski et al. 2014] to place the boundary, the base of the Upper Turonian Substage could coincide with the base of the Prionocyclus wyomingensis Zone or even be within the Prionocyclus macombi Zone (as about twenty S. bravaisianus were collected 100 $\mathrm{m}$ below the base of the Prionocyclus novimexicanus Zone and $33 \mathrm{~m}$ below the occurrence of a $P$. cf. wyomingensis - determination confirmed par W.J. Kennedy - in marls of the Kef Formation in Central Tunisia; cf. Amédro in Robaszynski et al. 2000).

It remains now to understand the circumstances and events that permitted the migration of numerous Romaniceras mexicanum, Prionocyclus hyatti and Coilopoceras cf. springeri from the U.S. Western Interior as far as southern France towards the end of Middle Turonian times.

Isolated specimens of ammonites originating from North America and belonging to the genera Borissiakoceras, Budaiceras, Metengonoceras, etc., had already been found in the Cenomanian of the Paris Basin (Kennedy and Juignet 1973, 1984; Kennedy et al. 1990; 


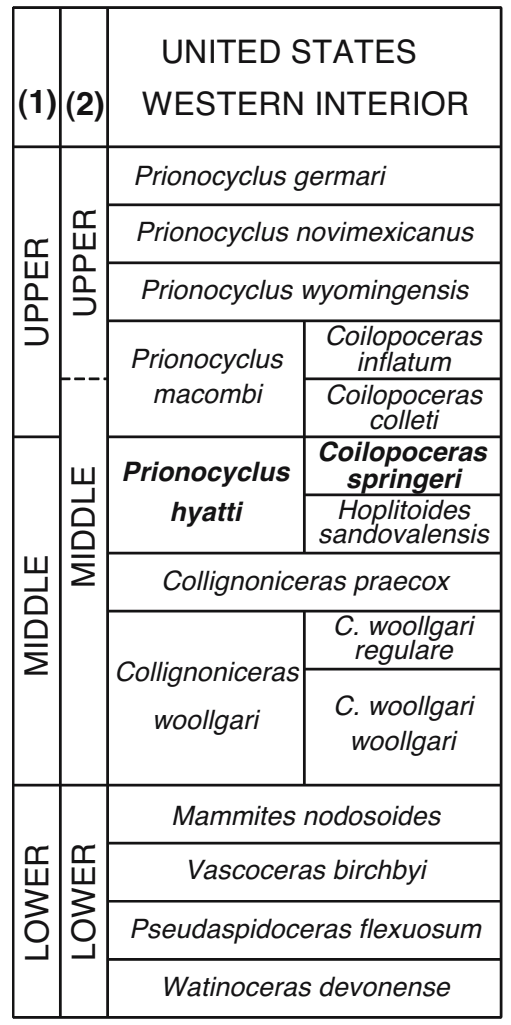

\begin{tabular}{|c|c|c|c|c|}
\hline \multicolumn{3}{|c|}{$\begin{array}{l}\text { WESTERN } \\
\text { EUROPE }\end{array}$} & $(1)$ & (2) \\
\hline \multicolumn{3}{|c|}{ Prionocyclus germari } & \multirow{3}{*}{$\begin{array}{l}\frac{\Upsilon}{4} \\
\frac{u}{0} \\
\frac{n}{2}\end{array}$} & \multirow{3}{*}{$\begin{array}{l}\frac{1}{山} \\
\frac{0}{0} \\
\frac{\square}{\supset}\end{array}$} \\
\hline \multicolumn{3}{|c|}{$\begin{array}{c}\text { Subprionocyclus } \\
\text { bravaisianus }\end{array}$} & & \\
\hline $\begin{array}{c}\text { Romaniceras } \\
\text { deverianum }\end{array}$ & & $?$ & & \\
\hline $\begin{array}{l}\text { Romaniceras } \\
\text { mexicanum }\end{array}$ & $\begin{array}{l}\frac{1}{0} \\
\frac{0}{0} \\
\frac{0}{0}\end{array}$ & & \multirow{4}{*}{ 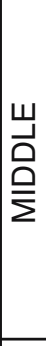 } & \multirow{4}{*}{ 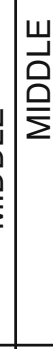 } \\
\hline $\begin{array}{l}\text { Romaniceras } \\
\text { ornatissimum }\end{array}$ & 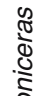 & regulare & & \\
\hline $\begin{array}{c}\begin{array}{c}\text { Romaniceras } \\
\text { kallesi }\end{array} \\
\end{array}$ & 5 & Collignoc. & & \\
\hline \begin{tabular}{|c|}
$\begin{array}{c}\text { Kamerunoceras } \\
\text { turoniense }\end{array}$ \\
\end{tabular} & రి & woollgari & & \\
\hline \multicolumn{3}{|c|}{ Mammites nodosoides } & \multirow{3}{*}{$\sum_{0}^{\infty}$} & \multirow{3}{*}{ 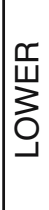 } \\
\hline \multicolumn{3}{|c|}{ Fagesia catinus } & & \\
\hline Watinoceras & $d e v$ & nense & & \\
\hline
\end{tabular}

Text-fig. 4. Correlation of the Turonian ammonite successions between the western Interior of the United States and western Europe. The co-occurence of Romaniceras mexicanum, Prionocyclus hyatti and Coilopoceras cf. springeri supports a precise correlation between the two areas during the late Middle Turonian. Two views prevail to define the middle-upper Turonian boundary: (1) the FO of Romaniceras deverianum (this work and as recommended during the Colloquium on the Turonian stage held in Paris in 1981; cf. Robaszynski compiler, 1983) and (2) the FO of Subprionocyclus bravaisianus (d'Orbigny, 1841) $[=S$. neptuni (Geinitz, 1850)]
Amédro et al. 2002). The rarity of these finds in the field suggests that they are probably empty, drifted shells conveyed, post-mortem, by oceanic surface currents (Kennedy and Cobban 1976). Nevertheless, it is interesting to note that most of the arrivals of "exotic" ammonites in Europe during the Cenomanian coincided with transgressive intervals of $3^{\text {rd }}$ order sequences, corresponding to temporary elevations of sea-level (Amédro et al. 2002). At the end of the Middle Turonian, the migration of an abundant population of Romaniceras, Prionocyclus and Coilopoceras appears to correspond to a comparable eustatic context. The sequence interpretations of the Turonian in Central Tunisia, in the AngloParis Basin and in north-western Europe, as proposed recently by Robaszynski et al. (1990), Gale (1996), Hardenbol et al. (1998) and Miller et al. (2005) all support the view that the uppermost levels of the Middle Turonian correspond to the end of a transgressive interval of a $3^{\text {rd }}$ order eustatic cycle, indeed the beginning of a highstand systems tract. Thus, when there is a temporary eustatic sea-level rise, one can imagine that a part of the ammonite population living in the Western Interior sea might pass in the Gulf of Mexico and be swept along by oceanic currents of the Proto-Atlantic for several thousands of kilometres to Europe (Luyendyk et al. 1972). If we are right, it is not impossible that future collecting in the Turonian of northern Africa or in the Iber- ian Peninsula may reveal the same "exotic" association as found in the Uchaux - la Cèze massifs.

\section{CONCLUSIONS}

The collecting of nearly one hundred specimens of Romaniceras mexicanum, Prionocyclus hyatti and Coilopoceras cf. springeri in the Turonian sandstone formations of the Uchaux and la Cèze massifs in the southeast of France is very interesting from four points of view: 1. Till now, this association was known only in the U.S. Western Interior and in the Gulf Coastal region and was considered as endemic;

2. A new Romaniceras mexicanum ammonite Zone is recognised at the end of the Middle Turonian in northwest Europe between the Romaniceras ornatissimum Zone below and the Romaniceras deverianum Zone above;

3 . For the first time a direct correlation becomes possible between the Middle Turonian of the United States of America and Western Europe;

4. Finally, it is suggested that the migration of this ammonite population from northern America to Europe could be the consequence of an eustatic event linked to a transgressive or a highstand systems tract near the end of the Middle Turonian. 


\section{Acknowledgements}

Francis Amédro would like to express his sincere thanks to Bill Cobban, Denver, Colorado, USA ( $\dagger$ ) and to Jim Kennedy, Oxford, UK, for discussions on the North American species $R$. mexicanum, $P$. hyatti and $C$. cf. springeri. In other respects Francis Robaszynski thanks Patricia Rowland, Oms, Pyrénées orientales, who accepted to read and improve the English translation of the text. We are also deeply grateful to Ireneusz Walaszczyk for help and remarks on the first draft of this paper.

\section{REFERENCES}

Amédro, F., Cobban, W.A., Breton, G. and Rogron, P. 2002. Metengonoceras teigenense Cobban \& Kennedy, 1989: une ammonite exotique d'origine nord-américaine dans le Cénomanien de Basse Normandie. Bulletin trimestriel de la Société Géologique de Normandie et des Amis du Muséum du Havre, 87, 5-28.

Cobban, W.A. 1984. Mid-Cretaceous ammonite zones, Western Interior, United States. Bulletin of the Geological Society of Denmark, 33, 71-89.

Cobban, W.A. and Hook, S.C. 1979. Collignoniceras woollgari woollgari (Mantell) ammonite faunas from the Upper Cretaceous of Western Interior, United States. New Mexico Bureau of Mines and Mineral Resources Memoir, 37, $51 \mathrm{pp}$.

Cobban, W.A. and Hook, S.C. 1980. The Upper Cretaceous (Turonian) ammonite family Coilopoceratidae Hyatt in the Western Interior of the United States. United States Geological Survey Professional Papers, 1192, 28 pp.

Devalque, C., Amédro, F., Philip, J. and Robaszynski, F. 1983. État des corrélations litho-biostratigraphiques dans le Turonien des massifs d'Uchaux et de la Cèze. Les zones d'ammonites et de rudistes. Mémoires du Muséum national d'Histoire naturelle, Paris, C, Sciences de la Terre, Colloque sur le Turonien, 49, 57-69.

Gale, A.S. 1996. Turonian correlation and sequence stratigraphy of the Chalk in southern England. In Hesselbo, S.P. and Parkinson, D.N. (Eds), Sequence stratigraphy in British Geology. Geological Society, Special Publication, 103, 177-195.

Geinitz, H.B. 1849-1850. Das Quadersandsteingebirge oder Kreidegebirge in Deutscland. 293 pp. Craz and Gerlach; Freiberg.

Hancock, J.M., Kennedy, W.J. and Cobban, W.A. 1993. A Correlation of the Upper Albian to basal Coniacian sequences of Northwest Europe, Texas and the United States Western Interior. Geological Association of Canada, Special Paper, 39, 453-476.

Hardenbol, J., Thierry, J., Farley, M.B., Jacquint, T., Graciansky, P.-C. and Vail, P. 1998. Mesozoic and Cenozoic se- quence chronostratigraphic framework of European basins. SEPM Special Publications, 60, 1-13.

Hébert, E. and Toucas, A. 1875. Description du bassin d'Uchaux. Annales des Sciences géologiques, 6, 112 pp.

Hyatt, A. 1903. Pseudoceratites of the Cretaceous. United States Geological Survey Monograph, 44, 351 pp.

Jones, T.S. 1938. Geology of Sierra de la Peña and paleontology of the Indidura Formation, Coahuila, Mexico. Bulletin of the Geological Society of America, 49, 69-150.

Kennedy, W.J. 1984. Description of the lectotype of Ammonites deverianus d'Orbigny, 1841 (Cretaceous Ammonoidea), Geobios, 24, 309-313.

Kennedy, W.J., Bilotte, M. and Melchior, P. 2015. Turonian ammonite faunas from the southern Corbières, Aude, France. Acta Geologica Polonica, 65, 437-494.

Kennedy, W.J. and Cobban, W.A. 1976. Aspect of ammonite biology, biogeography, and biostratigraphy. Special Papers in Palaeontology, 17, 94 pp.

Kennedy, W.J. and Cobban, W.A. 1988 a. The Upper Cretaceous ammonite Romaniceras Spath, 1923 in New Mexico. New Mexico Bureau of Mines and Mineral Resources Bulletin, 114, 23-34.

Kennedy, W.J. and Cobban, W.A. 1988 b. Mid-Turonian ammonite faunas from northern Mexico. Geological Magazine, 125, 593-612.

Kennedy, W.J., Cobban, W.A., Hancock, J.M. and Hook, S.C. 1989. Biostratigraphy of the Chispa Summit Formation at its type locality : a Cenomanian through Turonian reference section for Trans-Pecos Texas. Bulletin of the Geological Institutions of the University of Uppsala, 15, 39-119.

Kennedy, W.J., Cobban, W.A. and Landmann, N.H. 2001. A revision of the Turonian members of the Ammonite subfamily Collignoniceratinae from the United States Western Interior and Gulf Coast. Bulletin of the American Museum of Natural History, 267, 148 pp.

Kennedy, W.J. and Juignet, P. 1973. First record of the ammonite family Binneyitidae in Western Europe. Journal of Palaeontology, 47, 900-902.

Kennedy, W.J. and Juignet, P. 1984. A revision of the ammonite faunas of the type Cenomanian. 2. The families Binneyitidae, Desmoceratidae, Engonoceratidae, Placenticeratidae, Hoplitidae, Schloenbachiidae, Lyelliceratidae and Forbesiceratidae. Cretaceous Research, 5, 93-161.

Kennedy, W.J., Juignet, P. and Girard, J. 1990. Budaiceras hyatti (Shattuck, 1903), a North American index zone ammonite from the Lower Cenomanian of Haute-Normandie, France. Neues Jahrbuch für Geologie und Paläontologie, Abhandlungen, Monatshefte, 9, 525-535.

Kennedy, W.J., Walaszczyk, I. and Cobban, W.A. 2000. Pueblo, Colorado, USA, candidate Global Boundary Stratotype Section and Point for the base of the Turonian Stage of the Cretaceous, and for the base of the Middle Turonian Substage, with a revision of the Inoceramidae 
(Bivalvia). Acta Geologica Polonica, 50, 295-334.

Kennedy, W.J. and Wright, C.W. 1984. The Cretaceous ammonite Ammonites requienianus d'Orbigny. Palaeontology, 27, 281-293.

Kennedy, W.J., Wright, C.W. and Hancock, J.M. 1980. The European species of the Cretaceous ammonite Romaniceras with a revision of the genus. Palaeontology, 23, 325-362.

Luyendyk, B.P., Forsyth, D. and Phillips, J.D. 1972. Experimental approach to the palaeocirculation of the oceanic surface waters. Bulletin of the Geological Society of America, 83, 2649-2664.

Mantell, G.A. 1822. The fossils of the South Downs; or illustrations of the geology of Sussex. xvi +327 pp. Lupton Relfe; London.

Marcinowski, R., Walaszczyk, I. and Olszewska-Nejbert, D. 1996. Stratigraphy and regional development of the midCretaceous (Upper Albian through Coniacian) of the Mangyshlak Moutains, Western Kazakstan. Acta Geologica Polonica, 6, 60 pp.

Marcou, J. 1858. Geology of North America; with two reports on the prairies of Arkansas and Texas, the Rocky Mountains of New Mexico and the Sierra Nevada of California. 144 pp. Zürdur and Furrer ; Zurich.

Mennessier, G. 1950. Monographie géologique du massif d'Uchaux. Bulletin du Service de la Carte géologique de la France et des Topographies souterraines, 227, $50 \mathrm{pp}$.

Miller, K.G., Kominz, M.A. and Browining, J.V. 2005. The Phanerozoic record of global sea-level change. Science, 312, 1293-1298.

Morrow, A.L. 1935. Cephalopods from the Upper Cretaceous of Kansas. Journal of Paleontology, 9, 463-473.

Orbigny, A. d'. 1840-1842. Paléontologie française. Terrains Crétacés, t. 1. Céphalopodes, Paris, Masson, 662 pp.

Orbigny, A. d'. 1850. Prodrome de Paléontologie stratigraphique universelle des animaux Mollusques et rayonnés faisant suite au cours élémentaire de paléontologie et de géologie stratigraphiques, 2, 1-427. Masson; Paris.

Orbigny, A. d'. 1852. Cours élémentaire de Paléontologie et de Géologie stratigraphique. Paris, Masson, 847 pp.

Reeside, J.B. and Cobban, W.A. 2000. Studies of the Mowry Shale (Cretaceous) and contemporary formations in the United States and Canada. United States Geological Survey Professional Papers, 355, 126 pp.

Robaszynski, F. (compiler) 1983. Conclusions au colloque sur le Turonien. Échelles biostratigraphiques intégrées. Mémoires du Muséum national d'Histoire naturelle, Paris, C, Sciences de la Terre, Colloque sur le Turonien, 49, 209-230.

Robaszynski, F., Amédro, F., Devalque, Ch. and Matrion, B. 2014. Le Turonien des massifs d'Uchaux et de la Cèze (S.E. France). Migration globale d'ammonites et conséquences sur la zonation internationale, rudistes et corrélations entre les massifs. Académie royale de Belgique,
Mémoires de la Classe des Sciences, 2, 197 pp.

Robaszynski, F., Caron, M., Amédro, F., Dupuis, C., Hardenbol, J., González Donoso, J.-M., Linares, D. and Gartner, S. 1994. Le Cénomanien de la région de Kalaat Senan (Tunisie centrale): Litho-Biostratigraphie et interprétation séquentielle. Revue de Paléobiologie, 12, 351-505.

Robaszynski, F., Caron, M., Dupuis, C., Amédro, F., González Donoso, J.-M., Linares, D., Hardenbol, J., Gartner, S., Calandra, F. and Deloffre, R. 1990. A Tentative integrated Stratigraphy in the Turonian of central Tunisia : formations, zones and sequential stratigraphy in the Kalaat Senan area. Bulletin des Centres de Recherche, Exploration-Production d'Elf-Aquitaine, 14, 213-384.

Robaszynski, F., González Donoso, J.-M., Linares, D., Amédro, F., Caron, M., Dupuis, C., Dhondt, A. and Gartner, S. 2000. Le Crétacé supérieur de la région de Kalaat Senan, Tunisie centrale. Litho-biostratigraphie intégrée : zones d'ammonites, de foraminifères planctoniques et de nannofossiles du Turonien supérieur au Maastrichtien. Bulletin des Centres de Recherche, Exploration-Production d'Elf-Aquitaine, 22, 359-490.

Roberts, L.N. and Kirschbaum, M.A. 1995. Paleogeography of the Late Cretaceous of the Western Interior of Middle North America. Coal distribution and sediment accumulation. United States Geological Survey Professional Papers, 1561, $63 \mathrm{pp}$.

Roman, F. and Mazeran, P. 1913. Monographie paléontologique de la faune du Turonien du bassin d'Uchaux et de ses dépendances. Archives du Muséum d'Histoire naturelle de Lyon, 12, 137 pp.

Smith, A.G., Smith, D.G. and Funnel, B.M. 1994. Atlas of Mesozoic and Cenozoic coastlines, 110 pp. Cambridge University Press; Cambridge.

Sornay, J. 1950. Étude stratigraphique sur le Crétacé supérieur de la vallée du Rhône entre Valence et Avignon et des régions voisines. Thèse, Allier, Grenoble, $254 \mathrm{pp}$. and in Travaux du Laboratoire de Géologie de la Faculté des Sciences de l'Université de Grenoble, 27, 35-278.

Stanton, T.W. 1894. The Colorado Formation and its invertebrate fauna. United States Geological Survey Bulletin, 109, $288 \mathrm{pp}$.

William, G.D. and Stelck, C.P. 1975. Speculations on the Cretaceous paleogeography of North America. In: Caldwell, W.G.E. (Ed.), The Cretaceous System in the Western Interior of North America. Geological Association of Canada, Special Paper, 13, 1-20.

Wright, C.W. 1979. The ammonites of the English Chalk Rock (Upper Turonian). Bulletin of the British Museum Natural History (Geology), 3, 281-332.

Manuscript submitted: $15^{\text {th }}$ May 2016

Revised version accepted: $20^{\text {th }}$ Novemeber 2016 
PLATES 1-3 


\section{PLATE 1}

Prionocyclus hyatti (Stanton, 1894)

A, B - from SE Chapus, lithological unit UL 4 ; C, D - from $\mathrm{W}_{1}$ Chapus, UL 4 ; Tm4, Romaniceras mexicanum Zone. (scale bar $=2 \mathrm{~cm}$ ). Field localities and full descriptions of sections referred in the plates are given in Robaszynski et al. (2014). 

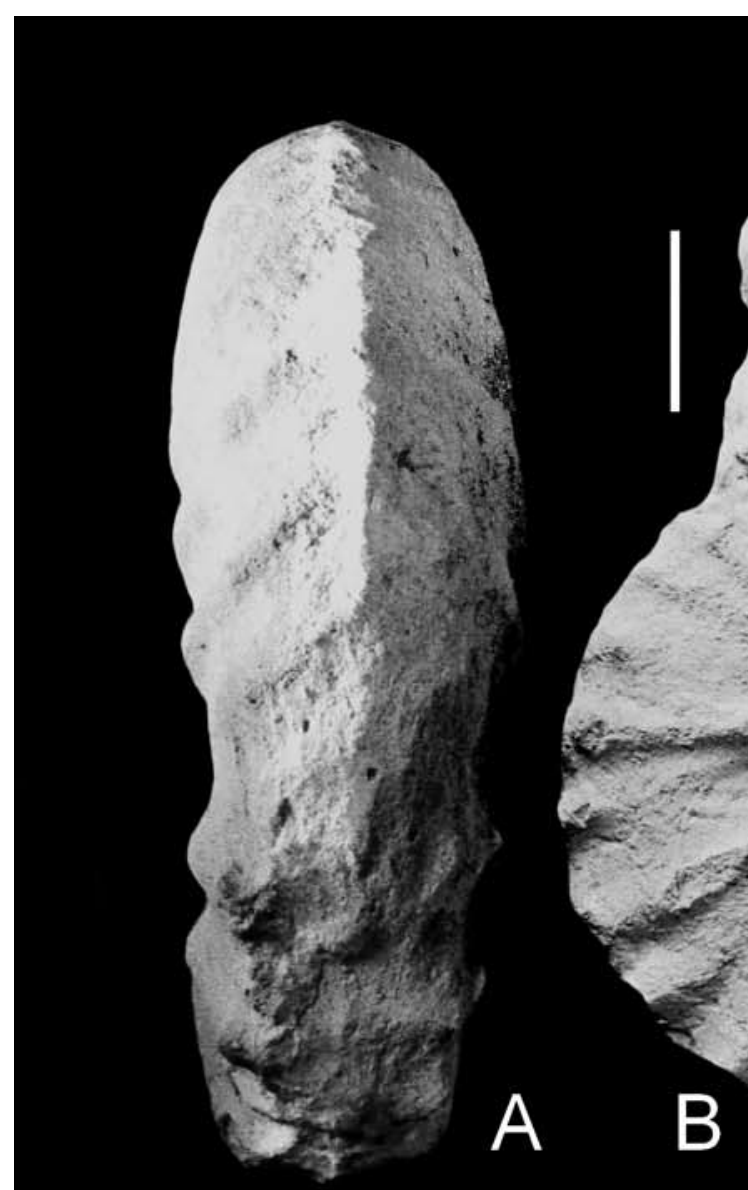


\section{PLATE 2}

Romaniceras (Romaniceras) mexicanum Jones, 1938

A, B - from $E_{2}$ Chansiergue, UL 5; C, D - from SE Peyras, UL 4 ; Tm4, Romaniceras. mexicanum Zone (scale bar $=2 \mathrm{~cm}$ ). Field localities and full descriptions of sections referred in the plates are given in Robaszynski et al. (2014). 


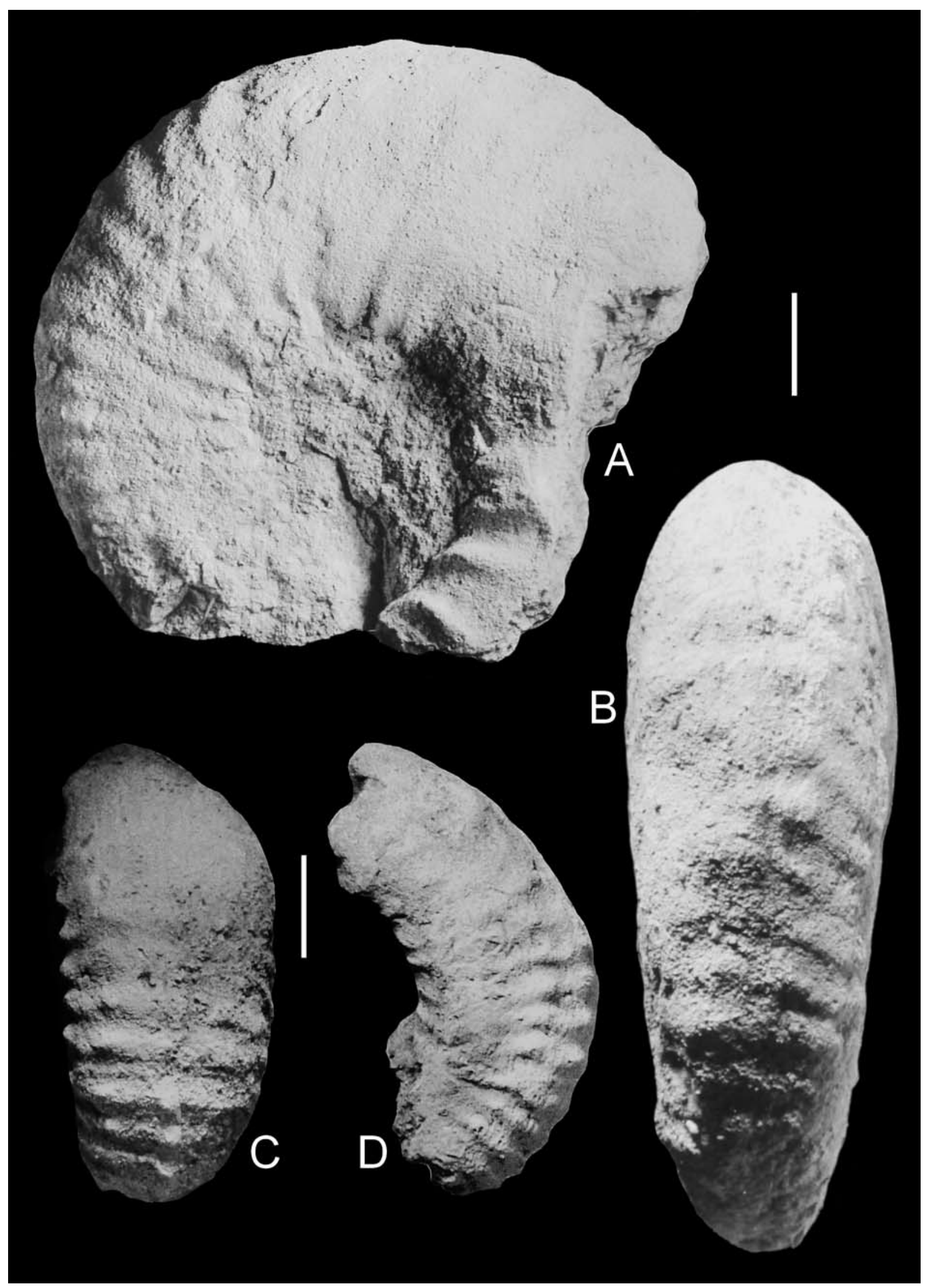




\section{PLATE 3}

A, B - Coilopoceras cf. springeri Hyatt, 1903, from S Peyras, UL 4, Tm4, Romaniceras mexicanum Zone.

C, D - Romaniceras (Romaniceras) mexicanum Jones, 1938, from SE Peyras, UL 4, Tm4, Romaniceras mexicanum Zone (scale bar $=2 \mathrm{~cm})$.

Field localities and full descriptions of sections referred in the plates are given in Robaszynski et al. (2014) 


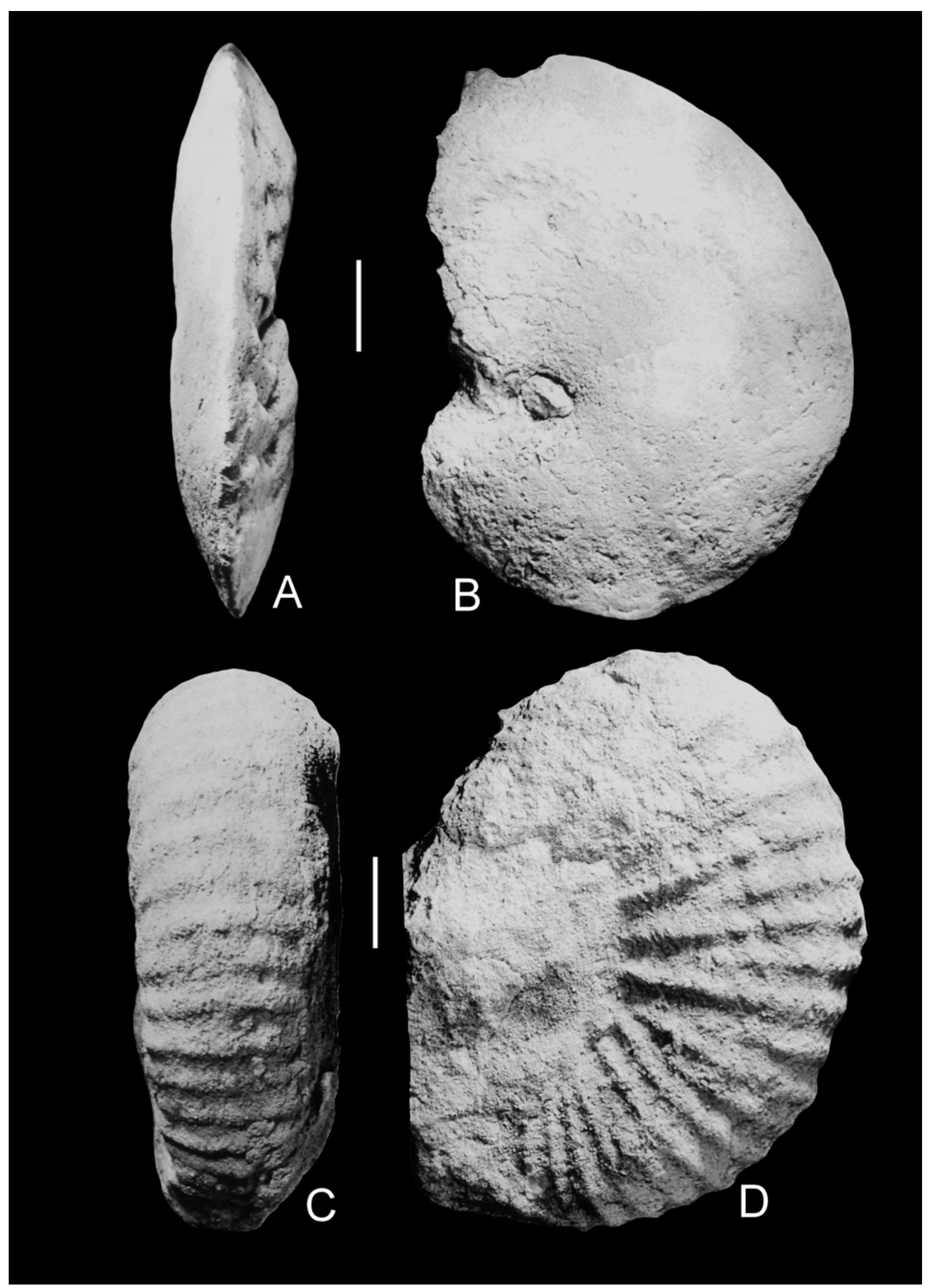

